\title{
Proses Perumusan Kebijakan Pemekaran Daerah (Studi di Pulau Sebatik Kabupaten Nunukan Kalimantan Utara)
}

\author{
Didi Febriyandi ${ }^{a} *$ \\ ${ }^{a}$ Universitas Brawijaya, Malang, Jawa Timur, Indonesia
}

\section{INFORMASI ARTIKEL}

\section{Article history:}

Dikirim tanggal: 27 Januari 2016

Revisi pertama tanggal: 12 Februari 2016

Diterima tanggal: 31 Mei 2016

Tersedia online tanggal 18 September 2016

Keywords: policy formulation process, role of local actors

\begin{abstract}
Expansion of the area if done a noble thing to reduce inequalities in public services and the welfare of society, especially in the border region Sebatik Island which is directly adjacent to the State Malaysia. In the process of formulation has traversed a long way from 2005 to 2015 Sebatik not yet bloomed. By rule Sebatik already complied with the procedures then to the center stage and for reasons that remain unclear policy process has not reached the desired goal together. As for the role of local actors has attempted to influence that although the outline deal happens area due to political factors to the division process to the center stage. It's just less escort and intensive communication on the elite center.
\end{abstract}

\section{INTISARI}

Pemekaran daerah jika dilakukan merupakan suatu hal yang mulia untuk mengurangi kesenjangan pelayanan publik dan kesejahtreraan masyarakat terutama pada wilayah perbatasan Pulau Sebatik yang mana berbatasan langsung dengan Negara Malaysia. Dalam proses perumusan jalan panjang telah dilalui dari tahun 2005 hingga 2015 sebatik belum juga dimekarkan. Secara aturan sebatik sudah memenuhi prosedur kemudian sampai pada tahapan pusat dan dengan alasan yang belum jelas proses kebijakan belum mencapai tujuan yang dinginkan bersama. Adapun peranan aktor lokal sudah berupaya dengan pengaruh yang dimiliki walaupun secara garis politik hingga proses pemekaran tersebut sampai pada tahapan pusat.

2016 FIA UB. All rights reserved.

\section{Pendahuluan}

Tantangan dewasa sepanjang waktu adalah bagaimana melakukan dan melaksanakan pemerintahan yang efektif dan efesien, artinya bahwa pemerintahan yang dapat membuat hasil yang baik bagi publik.Secara umum hadirnya kebijakan sebagai sistem standar, aturan dan prosedur dalam mewujudkan, menilai dengan kritis dan mesinergikan pengetahuan yang relevan dengan kebijakan. Memecahkan sebuah dinamika masalah masalah dalam pemahaman kegiatan sedangkan variabel pemecahan masalah adalah bentuk solusi yang ditawarkan sebagai kunci utama dalam menganalisis suatu kebijakan.

Memang kegiatan politik bisa berbagai macam bentuk, yaitu selalu ada sangkut pautnya dengan yang namanya kekuasaan. Diantara berbagai macam bentuk tersebut yang penting adalah pengambilan keputusan yakni kegiatan politik yang merupakan pengambilan keputusan akan menghasilkan suatu keputusan atau disebut juga dengan kebijakan publik. Ada beberapa penyebab sering terjadinya kegagalan pemerintah membangun kebijakan publik. Pertama, karena tidak mengerti makna intisari substansi kebijakan publik

* Corresponding author. Tel.: +62-812-33999445; e-mail: wisanggenifebriyandi@ gmail.com 
dampak panjangnya akan mengakibatkan reduksi teori kebijakan publik. Kedua, karena analis kebijakan antara ada dan tiada artinya ada tapi tidak bekerja secara maksimal dengan posisi pemerintah sebagai ahlinya bisa bekerja tapi tidak menghasilkan output secara bijaksana pada publik tapi lebih kepada dadakan ahli kebijakan publik.

Perhatian utama dari pemrakarsa kebijakan ditujukan pada sejauh manakah tujuan atau sasaran resmi kebijakan telah tercapai. Sedangkan para pejabat pelaksana dilapangan akan memberi perhatian pada masalah tindakan atau perilaku mereka dilapangan dalam menyikapi gangguan atau hambatan yang menghalangi berhasilnya suatu kebijaksanaan baru diwilayah kerjanya. Alur yang harus dipahami kemudian ialah dari proses kebijakan dari persfektif perubahan sosial dan politik, dimana kebijakan yang dibuat oleh pemerintah bertujuan untuk mengadakan perbaikan atau perubahan dalam masyarakat sebagai kelompok sasaran.

\section{Teori}

\section{Perumusan Kebijakan}

Kebijakan publik adalah apapun pilihan pemerintah untuk melakukan atau tidak melakukan (Dye, 2005). Jelas terlihat bahwa apa yang diputuskan pemerintah untuk dilakukan atau tidak dilakukannya itulah yang merupakan kebijakan publik Dalam pandangan David Easton ketika pemerintah membuat dan mengambil kebijakan publik, saat itu juga pemerintah mampu memberikan nilai-nilai terhadap masyarakat. Sedangkan Perumusan kebijakan merupakan tahapan dari rangkaian proses pembuatan dan pelaksanaan suatu kebijakan. Para ahli kebijakan mendefinisikan perumusan kebijakan yaitu: Dunn (2003:43), perumusan kebijakan adalah pegembangan alternatif pemecahan masalah. Sedangkan Islamy (2003:24) mengatakan perumusan kebijakan proses yang bertahap namun sulit untuk diselesaikan dengan baik, dan didalam kebijakan sangat penting diketahui peranan aktor dalam proses perumusan kebijakan tersebut.

Adapun menurut Islamy (2003:77) berpendapat ada empat langkah untuk proses pengambilan kebijakan publik, yaitu sebagai berikut:

a. Perumusan Masalah

Mengerti dan memahami suatu masalah dapat mempermudah menemukan asumsi yang tersembunyi, meraba penyebab, memetakan tujuan, mampu memadukan padangan yang bertentangan dan plan peluang kebijakan baru.

b. Agenda Kebijakan

Banyaknya masalah umum yang muncul dipermukaan hanya sedikit yang mendapatkan keseriusan dari pembuat kebijakan. c. Pemilihan Alternatif Kebijakan (Memecahkan Masalah)

Sesudah masalah publik didefinisikan dan para perumus kebijakan sepaham untuk memuat masalah tersebut ke dalam agenda kebijakan, maka kelanjutnnya adalah membuat pemecahan masalah. Pada tahapan ini biasanya para perumus kebijakan akan menghadapi pertarungan kepentingan antara berbagai aktor atau masing-masing aktor yang menawarkan alternatif dalam kondisi demikian pilihan-pilihan kebijakan akan sangat berdasarkan negosiasi dan kompromi kepentingan.

d. Tahapan Penetapan Kebijakan

Tahapan ini ialah tahapan akhir dari berbagai rangkaian yang coba di jelaskan di atas, sehingga mempunyai kekuatan hukum mengikat.

\section{Aktor Dalam Perumusan Kebijakan}

Mengenai bahasan kebijakan publik, aktor sangat mempunyai posisi strategis bersama dengan kelembagaan kebijakan. Hubungan aktor dan kelembagaan ialah penentu proses perjalanan dinamika dan strategi yang dilakukan oleh ruang lingkup kebijakan. Prinsipnya aktor kebijakan adalah orang, baik sebagai perumus maupun kelompok penekan kebijakan yang proaktif dan aktif dalam interaksi di dalam analisis kebijakan publik. Menurut Howlett dan Ramesh dalam Madani (2011:37) aktor kebijakan meliputi aktor internal dan aktor eksternal yang mempunyai kosern tersendiri terhadap kebijakan. Aktor personal ataupun kelompok berperan dalam setiap perbincangan dan perdebatan tentang kebijakan publik. Dapat kita simpulkan dari pendapat ahli bahwa aktor kebijakan yaitu seorang atau sekelompok orang yang terlibat dalam penentu kebijakan baik itu pada proses perumusan, implementasi dan evaluasi kebijakan. Dalam gejolak perhatian ragam dan pendekatan memahami berbagai aktor yang terlibat di suatu proses kebijakan publik, maka konsep dan konteks aktor sangat terkait dengan macam serta tipologi kebijakan yang akan dianalisis. Adapun dalam sudut padang perumusan kebijakan maka aktor mempunyai andil besar untuk keterlibatan secara penuh yang kemudian di bagi menjadi dua kelompok yaitu kelompok dalam birokrasi dan kelompok di luar birokasi.

Menurut Islamy (2003:47) berpandangan kelompok yang terlibat dalam proses perumusan kebijakan adalah kelompok formal dan kelompok non formal. Kelompok formal ialah badan-badan administratif pemerintah yang meliputi; eksekutif, legislatif dan yudikatif. Sementara kelompon non formal terdiri dari:
a. Kelompok kepentingan
b. Partai Politik
c. Warga Negara individual 
Secara rinci sebagai berikuti:

a. Eksekutif (presiden, menteri, gubernur dan bupati/walikota)

b. Legislatif (DPR DPD dan DPRD)

c. Aktor Privat (kelompok kepentingan, organisasi sosial dan asosiasi)

d. Aktor Civil Society (Lembaga dalam masyarakat, lingkungan sekitar, kelompok RW, RT)

Kelompok tersebut kemudian dianalisis secara mendalam dan detail untuk mengetahui aktor kebijakan yang sering terlibat dalam proses perundingan dan pengambilan kebijakan internal yang dapat berupa; mereka yang mempunyai kekuasaan (eksekutif, legislatif, yudikatif). Partisipan atau aktor yang tidak resmi wujudnya seperti partai politik dan lembaga swadaya masyarakat dan akademisi yang dapat mendukung kebijakan, member masukan atau menolak kebijakan yang dibuat.

\section{Metode Penelitian}

\section{Jenis Penelitian}

Kita mendefinisikan metodologi kualitatif sebagai prosedur penelitian yang menghasilkan data deskriptif berupa kata-kata tertulis atau lisan dari orang-orang dan perilaku yang dapat diamati. Data deskriptif kualitatif sebagai pembanding terhadap fenomena yang terjadi dilapangan yang mengarah pada tujuan terhadap sasaran penelitian.

\section{Lokasi dan Situs Penelitan}

Hal ini utarakan Moleong (2005: 26) bahwa cara terbaik yang bisa ditempuh dalam penentuan lapangan penelitian adalah dengan jalan bahwa penulis berangkat ke lapangan untuk mengadakan pengamatan tentang suatu fenomena dalam keadaan ilmiah. Penjelasan tersebut peneliti ketika menuju tempat suatu obyek yang diteliti agar bisa mengungkapkan suatu data valid untuk dilakukan deskriptif berkaitan dengan fenomena di lapangan.

Berdasarkan penjelasan tersebut, maka penelitian ini dilakukan di Kab. Nunukan. Penetapan lokasi penelitian pada Kabupaten Nunukan, Kecamatan Sebatik Induk dan Sebatik Barat.

Mengenai situs penelitain sebagai pokok bahasan utama untuk memperoleh data yang relevan sebagai gambaran terhadap obyek yang akan diteliti yakni di Bagian Pemerintahan Kabupaten Nunukan, Camat Sebatik Induk, Camat Sebatik Barat, Kepala Desa Tanjung Karang, Kepala Desa Binalawan, ketua Himpunan Masyarakat Sebatik (HMS), Bupati Nunukan dan Ketua DPRD Kabupatena Nunukan. Dalam hal ini semua Lembaga Organisasi tersebut memiliki peran dalam penentuan kebijakan Pemekaran Daerah Pulau Sebatik Menjadi Kota Sebatik.

\section{Fokus Penelitian}

Fokus dalam penelitian ini, antara lain sebagai berikut:

a) Proses Perumusan Kebijakan Pemekaran Daerah Pulau Sebatik

- Perumusan masalah kebijakan

- Agenda kebijakan

- Alternatif kebijakan

- Penetapan kebijakan

b) Peranan aktor lokal dalam pengawalan proses perumusan Kebijakan pemekaran daerah yang mempunyai pengaruh akan goalnya Pemekaran Daerah Pulau Sebatik

\section{Sumber Data dan Informan}

Adapun jenis sumber data adalah sebagai berikut:

1. Data primer; Aktor Lokal

2. Sementara data sekunder; yaitu Undang-Undang Pemekaran daerah.

\section{Hasil Penelitian dan Pembahasan}

\section{Proses Perumusan Kebijakan}

Proses perumusan kebijakan sebagai sebuah rangkaian penting dalam pengambilan sebuah kebijakan dan keputusan pemekaran daerah memerlukan beberapa ketentuan-ketentuan vital berupa kesiapan daerah secara makro dan mikro. Namun dalam gaya proses perumusan kebijakan terdapat startegi komunikasi dan negoisasi dibangun dalam kerangka meloloskan pulau sebatik sebagai sebuah kabupaten kota yang baru.

Kemudian dibagi menjadi beberapa proses perumusan sebagai berikut:

\section{a) Perumusan Masalah}

Dalam hal ini secara garis besar kita mengerti, memahami suatu masalah, meraba dan menemukan tujuan. Konteks proses perumusan kebijakan pemekaran daerah pulau sebatik diawali pada keinginan dan kebutuhan besar dilakukannya pemekaran daerah karena dari berbagai solusi belum ada signifikan kemajuan pulau sebatik dari berbagi segi diantaranya. Letak geografis pulau sebatik yang berpisah dengan kabupaten Nunukan, Pengelolaan potensi daerah yang sangat minim. Pelayanan masyarakat yang tidak efektif, Infrastuktur jalanan yang parah. Apalagi memang secara letak geografis kabupaten induk Nunukan berpisah pulau dengan Sebatik. Proses perumusan kebijakan pemekaran daerah Pulau Sebatik sebagai sebuah wacana yang terbilang masih segar diperjuangkan, pemekaran pulau sebatik tercatat sejak tahun 2005 mulai digulirkan dengan disertai berbagai pertimbangan yang logis. 
Sebagai daerah yang berbatasan langsung dengan Malaysia, akselerasi pembangunan sangat diperlukan. Dan pembentukan daerah baru menjadi Kabupaten Sebatik adalah jalan alternatif dan paling rasional dilakukanketika wacana ini muncul bersamaan dengan acara Kecamatan Sebatik dimana berbagai elemen masyarakat tergabung seperti Camat Sebatik, Kapolsek Sebatik dan Danramil serta pemuda-pemuda Sebatik membicarakan pemekaran Pulau Sebatik rangkaian awal ini tercetus dikarenakan melihat kondisi sebatik yang strategis dan perlu untuk ditingkatkan statusnya. Berdasarkan isu masif yang penting disebabkan oleh beberapa faktor yaitu: Letak geografis pulau sebatik yang berpisah dengan Kabupaten Nunukan, Pengelolaan potensi daerah yang sangat minim, Pelayanan masyarakat yang tidak efektif, dan Infrastruktur jalanan yang parah. Kemudian selanjutnya ialah Minimnya anggaran dalam pendanaan di bidang pertahanan dan keamanan nasional Indonesia. Tahun 2006 digulirkan dengan sosialisasi masif oleh pemuda sebatik ke beberapa desa yang ada di Sebatik lalu bertepatan dengan adanya kunjungan Pemerintah Pusat yang melihat kondisi perbatasan hanya dari pusat memberikan janji pembangunan terhadap daerah perbatasan. Dan tahun 2007 berdasarkan pertimbangan yang panjang dibentuklah sebuah tim khusus yang bertugas mengorganisir rencana Pemekaran Kota Sebatik, maka terbentuklah Tim Wahana Pemekaran Sebatik (Himpunan Masyarakat Sebatik) yang secara substansi mewadahi dan mengakomodir aspirasi serta mengawal kelengkapan administrasi terhadap proses pengusulan pemekaran daerah. Tahun 2008-2010 merupakan tahun yang cukup menentukan langkah yang selanjutnya ditahun 2011 dirangkai dengan kompromi dan lobi politik tingkatan lokal pada momen pemilihan Bupati Nunukan ke salah satu calon.

\section{b) Agenda kebijakan (Setting)}

Titik isu yang tidak bisa diabaikan lagi terjadi pada tahun 2012 setelah melalui proses berbelit dari isu tingkatan bahwa agar satu kesatuan dalam berpandangan Pulau Sebatik harus mekar dengan upaya dari bawah yakni melegalitasnya persetujuan administrasi dukungan di desa-desa hingga lewat kompromi lobi deal politik dimomen pemilihan Bupati Nunukan bertepatan dari hasil kajian akademis Universitas Airlangga yang membuat jalan untuk pemekaran terbuka lebar. Hal ini terbukti dari sikap dan dukungan juga dari elite politik lokal yang ada di legislatif tidak ada sama sekali perdebatan panjang apalagi kompromi yang menggunakan money politic agar mempercepat proses pemekaran Pulau Sebatik. Banyaknya masalah umum yang muncul salah satunya dengan sikap setuju tapi tidak dengan serius memikirkan dampak kebijakan yang telah ditetapkan dan hanya sedikit yang mendapatkan keseriusan dan komitmen pembuat kebijakan dari pemerintah dalam memasifkan sebuah isu penting dan yang berperan penting untuk pengawalan isu tersebut adalah Tim wahana pemekaran Sebatik (HMS) dan Bupati Nunukan Drs. H. Basri.

\section{c) Alternatif kebijakan}

Dari masalah publik yang sudah berusaha didefiniskan dan aktor kebijakan sepaham untuk memuat masalah tersebut ke dalam agenda kebijakan dan pada tahapan ini besar pertarungan kepentingan aktor yang menawarkan sesuatu lebih berdasarkan negosiasi dan kompromi kepentingan. Adapun puncak perjuangan proses perumusan kebijakan pemekaran daerah adalah pada tahun 2011 yang merupakan sebagai tahun politik pemilihan Bupati Kabupaten Nunukan menjadikan isu kebijakan ini begitu sangat strategis. Sebagai tim wahana pemekaran sebatik berbagai cara telah dilakukansalah satunya dengan membangun kesepakatan dari salah satu calon Bupati Nunukan yakni Drs. H. Basri yang kemudian beliau terpilih sebagai Bupati, Langkah mitra politik tersebut yang membuat proses kebijakan ini berlangsung dengan baik. Pengawalan dan sikap serius terlihat ditahun 2012 dari mekarnya beberapa kecamatan baru di Pulau Sebatik yang sebelumnya hanya 2 kecamatan yaitu Kecamatan Sebatik Barat dan Kecamatan Sebatik namun karena untuk kepentingan prasyarat pemekaran daerah kabupaten/ kota haruslah memenuhi kreteria dengan minimal 4/5 kecamatan dengan usaha yang ada dari Pemkab Nunukan khususnya Bupati Nunukan akhirnya Pulau Sebatik dimekarkan kecamatannya yakni pemekaran; Kecamatan Sebatik Timur, Sebatik Utara, Sebatik Tengah kemudian secara tinjauan akademis juga sudah dilakukan dari Universitas Airlangga yang menghasilkan kelayakan pemekaran daerah Sebatik untuk menjadi Kota.

\section{d) Penetapan kebijakan}

Tahapan yang satu ini ialah akhir dari berbagai rangkaian yang coba dijelaskan di atas, sehingga mempunyai kekuatan hukum yang mengikat. Terlihat jelas pada kajian akademis Usulan daerah otonomi baru Kota Sebatik Kalimantan Utara yang dilakukan oleh Universitas Airlangga Surabaya yang dipublikasikan pada tanggal 25 April 2012 menyatakan Sebatik layak menjadi daerah otonom Baru.

\section{Peranan Aktor Pemerintah Daerah}

\section{a. Kepala Desa Tanjung Karang \& Binalawan}

Sebagai salah satu kelompok formal dan aktor eksekutif peranan kepala Desa Tanjung Karang dalam menginisiasi usulan pemekaran dari akar rumput sangatlah besar. Mereka berhasil menginisiasi dan menjembatani aspirasi masyarkat desa yang kemudian di bawa ke Kecamatan. Sebagai aktor lokal yang tentunya mahfum betul dengan kondisi desa, tugas mereka dalam menjadi penghubung aspirasi sekaligus 
melengkapai beberapa berkas administrasi pemekaran cukup banyak membantu. Kerja-kerja komunikasi melalui rapat-rapat dengan $\mathrm{RT}$, RW, BPD dan tokoh masyarakat berhasil membangun sebuah sinergi kesadaran bahwa pemekaran pulau sebatik adalah demi kesejahteraan masyarakat bukan yang lain.

Proses perumusan kebijakan seperti ini mengusung prinsip transparansi sehingga meminimalisir kecurigaan dan konflik yang mungkin terjadi. Model partisipatif seperti ini akan menjaga kemurnian sebuah keputusan karena lahir dari perbincangan yang sehat. Proses perumusan seperti ini menggunakan analisa proses yang menjelaskan bahwa proses keputusan bersama tentang pentingnya Pemekaran di Pulau Sebatik merupakan hasil dari kompromi politik. Sebuah kompromi yang berhasil menyatukan semua pandangan bahwa Sebatik haruslah mekar demi kesejahteraan masyarkat Sebatik. Analisa proses juga melihat bahwa di Pulau Sebatik tingkat pembangunan ekonomi, sosial, budaya dan perdagangan yang belum maksimal sehingga diperlukan sebuah keputusan politik yakni rekomendasi Pemekaran yang selanjutnya di dorong ke tingkatan selanjutnya. Keputusan politik ini masih akan melewati proses yang panjang sehingga harus tetap dikawal dan disempurnakan.

\section{b. Camat Sebatik dan Sebatik Barat}

Keterlibatan Camat Sebatik dan Sebatik Barat dalam memberikan dukungan politik pada wacana pemekaran Pulau Sebatik memberikan beberapa keuntungan strategis. Dengan posisi jabatan strategis di birokrasi peran mereka sangat banyak membantu. Penjelasan mereka tentang beberapa rasionalisasi pentingya pemekaran Pulau Sebatik seperti dengan pemekaran Sebatik akan bisa lebih maju karena pembangunan menjadi terfokus, tidak akan adanya perebutan aset dengan daerah induk berhasil meyakinkan banyak pihak untuk setuju pada pemekaran ini.

Dukungan pada pemekaran ini juga dilakukan dengan melengkapi beberapa persyaratan administrasi pemekaran, mengumpulkan beberapa kepala desa, LSM, dan tokoh masyarakat untuk menyamakan persepsi. Langkah ini sangat baik agar ada kekompakan politik yang tentunya akan semakin memperlancar usulan. Dukungan moral dan politik akan semakin memperkuat perjuangan tim-tim Lobi pemekaran karena disokong penuh oleh birokrasi daerah.

c. DPRD Nunukan

Secara hakekat DPRD memiliki peran dalam pemekaran yakni:

- Mengeluarkan surat dukungan terhadap pemekaran daerah

- Menyiapkan Pansus (Panitia Khusus dalam melakukan kajian dan pemabahasan recana pemekaran daerah)
- Memberikan dan merekomendasikan dukungan melalui surat resmi terhadap pemekaran daerah, dan keputusan penting mengenai kandidat ibu kota di daerah baru serta dukungan dana-biaya dalam persiapan peyelenggaraan pemerintahan daerah baru.

- Memberikan rekomendasi sekaligus permohonan kepada DPRD Propinsi untuk dapat memberikan persetujuan terhadap rencana pemekaran wilayah

DPRD Nunukan sebagai salah satu aktor formal dan legislatif telah melakukan beberapa terobosan untuk mendukung terwujudnya Sebatik sebagai Kota/ DOB. Dukungan yang diwujudkan dalam mengeluarkan SK persetujuan dari DPRD Kab Nunukan agar sebatik menjadi kota sendiri. Peran DPRD Nunukan sangat dominan dalam konteks penentu dari pemenuhan persyaratan administratif. DPRD Nununukan selanjutnya berperan besar sebagai pemberi pertimbangan, pendukung, pengontrol dan sebagai mediator antara eksekutif dan masyarakat sekitar pendukung pemekaran Pulau Sebatik. Namun DPRD Nunukan dituntut mempunyai kemampuan kepemimpinan dan manajemen yang baik sehingga dapat melakukan komunikasi politik yang masif dan terukur.

\section{d. Bupati Nunukan}

Bupati selaku penanggungjawab sekaligus kepala daerah berperan sebagai berikut:

- Mengeluarkan surat dukungan dan persetujuan rencana pemekaran daerah berdasarkan aspirasi dukungan dari bawah melalui referendum surat resmi desa

- Melakukan jajak pendapat dengan daerah persiapan

- Mengeluarkan persetujuan dan mengajukan secara resmi surat permohonan pada Gubernur dan Kemendagri untuk rencana pemekaran daerah

- Memutuskan dan menetapkan daerah induk sebagai wakil yang mengkomunikasikan intensif dengan berbagai pihak di tingkat bawah dan pusat serta memfasilitasi tim kemendagri dan DPR RI untuk observasi lapangan

- Mengalokasikan anggaran bagi pemekaran daerah

Dalam konteks perumusan kebijakan Pemekaran Pulau Sebatik peran yang ditunjukan Bupati Nunukan sangatlah besar. Kerelaan dan kesedian Nunukan sebagai daerah induk untuk memberikan ruang persetujuan terhadap Pemekaran Pulau Sebatik sangat berarti besar. Tanpa persetujuan Nunukan sebagai daerah induk mustahil bagi wacana pemekaran Pulau Sebatik bisa melangkah lebih jauh. Jiwa besar yang ditunjukan. Dengan pemekaran rentang birokrasi akan semakin pendek yang tentunya akan mempermudah masyarakat dalam pelayanan publik serta pembangunan infrastruktur, ekonomi, sosial budaya dan politik akan 
lebih terfokus tapi balik perdebatan panjang serta komunikasi yang ruwet perjuangan sebatik tak lepas dari kepentingan bupati nunukan yakni Drs. H. Basri yang dulunya sebelum mencalonkan diri dan maju lalu kemudian terpilih menjadi bupati nunukan ada kontrak politik yang disepakati bersama dengan beberapa pihak termasuk Tim wahana Pemekaran bahwa ketika nanti menang Sebatik harus dijadikan Kota Sendiri yakni Daerah otonomi Baru. Di dalam rangkaian panjang ini kita bisa pahami bersama bahwa sebenarnya Pemekaran Daerah Pulau sebatik tidak hanya kemurnian yang dilakukan oleh masyarakat akan tetapi hal tersebut mampu menjadi titik temu kesepakatan kontrak politik dengan salah-satu calon bupati pada saat itu yaitu Drs. H. Basri yang kemudian menang dan mampu memuluskan kebutuhan masyarakat sebatik lewat kewenangan beliau selaku bupati bagi penulis ini bukan sekedar asumsi pribadi karena fenomena tersebut berdasarkan wawancara yang dilakukan oleh penulis kepada tim wahana pemekaran daerah sebatik hingga mengetahui motif-motif kebijakan pemekaran dikeluarkan oleh pemerintah daerah nunukan atas nama bupati.

e. Peranan Aktor Tim Wahana Pemekaran Sebatik

HMS adalah kelompok non formal. Sebagai sebuah kelompok kepentingan yang terdiri dari para aktor privat baik akademisi, tokoh masyarakat, LSM, dan lain-lain, disinilah kekuatan utama dalam mensukseskan keberhasilan Pemekaran Pulau Sebatik. HMS dengan fungsi inisiasi, identifikasi, pengorganisasian dan fungsi kontrol, wewenang mereka cukup besar. HMS lah secara resmi ditunjuk oleh pemerintah Daerah untuk melakukan komunikasi politik dan lobi politik ke Provinsi maupun ke Pusat. HMS yang bertanggungjawab mengawal jalannya proses pemekaran ini sampai selesai. Dengan kemampuan lintas sektor yang dimiliki harapan besar ada dipundak mereka. Keberhasilan meyakinkan Pemerintah Provinsi Kaltim dan DPRD Kaltim untuk memberikan rekomendasi kelayakan pemekaran Pulau Sebatik patut mendapatkan apresiasi. Wacana ini telah sampai di pusat dan akan akan dibahas di tahun 2016.

Tugas HMS tinggal selangkah lagi. Proses penyusunan kebijakan pemekaran pulau sebatik telah memasuki tahap akhir. Dipusat inilah perjuangan sesungguhnya. HMS harus mampu memaksmimalkan peluang yang ada dengan mengintensifkan komunikasi politik dengan pemerintah dan DPR RI. Pada tahap inilah biasanya intrik politik semakin gencar terjadi walaupun sebenarnya sudah terjadi beberapa lobi politik ditingkatan pusat akan tetapi dari beberapa usaha-usaha elemen yang tergabung khususnya tim Wahana Pemekaran Daerah Sebatik tetap teguh bersikap pada politik secara gerakan nyata yaitu kacamata untuk menuntaskan proses perumusan kebijakan pemekaran daerah pulau sebatik yang harus dilakukan secara murni tanpa tendensi politis. Disinilah kematangan dan kedewasaan menentukan sikap politk dibutuhkan agar Pemekaran Sebatik bisa segera terealisasi.Kemudian hal penting lainnya adalah komunikasi tingkat bawah yakni bagaimana HMS harus mampu memaksimalkan komunikasi terkait penyebaran informasi-informasi tentang perkembangan Pemekaran Daerah Pulau Sebatik di tingkatan desa bagi saya kebijakan tidak akan bisa berjalan sesuai relnya ketika salah-satu elemen penting kurang mampu berkomunikasi dengan masif yang nantinya akan berdampak pada kuatnya pro dan kontra yang lebih besar dan hal tersebut yang tidak di inginkan.

f. Peranan Kaum Intelektual

Intelektual adalah suatu kemauan seseorang dalam memperoleh ilmu pengetahuan dan mengamalkannya untuk hubungan sosial masyarakat dari berbagai masalah yang timbul. Sedangkan menurut David Wechler dalam Azwar (23:1996) mendefiniskan bahwa intelektual sebagai kumpulan dan totalitas keahlian seseorang untuk bertindak serta bersikap dengan mempunyai tujuan tertentu, berpikir rasional dan menghadapi lingkungan secara efektif. Sedangkan Alfred Binet dalam Islamy (21:1989) mengungkapkan intelektual sebagai kapasitas yang mencakup kemampuan menalar, menilai, mencipta, merumuskan arah berpikir dan mampu memiliki kemampuan mengkritik diri sendiri. Adapun permasalahan proses perumusan kebijakan pemekaran Kota Sebatik intelektual ini sudah melakukan tugasnya dengan baik untuk mengawal dan mengkritik secara solutif tentang kebijakan pengawalan Pemekaran daerah Kota Sebatik dari aksi demonstrasi sampai kritik lewat media sosial juga turut serta dilakukan artinya pengaruh untuk melakukan sesuatu yang ideal terus menerus digencarkan dari beberapa tahun terakhir namun sayangnya pengaruh tersebut seolah tak didengarkan aktor-aktor yang ada di dalam pemerintahan baik pusat dan daerah, yang terjadi hanya umbar janji momentum politik tapi dalam komitmen bersama satu persatu tak mendengarkan. Kekuatan yang teman-teman bangun diluar sistem pemerintahan tidak begitu berpengaruh besar hanya sebatas isu-isu walaupun sebenarnya ditujukan kepada sikap aktor daerah yang tidak mempunyai tekad keseriusan dalam mengawal kebijakan pemekaran daerah kota Sebatik yang ada ditingkatan pusat.

\section{Pembahasan}

Hubungan aktor dan kelembagaan ialah penentu proses perjalanan dinamika dan strategi yang dilakukan oleh ruang lingkup kebijakan. Prinsipnya aktor kebijakan adalah orang, baik sebagai perumus maupun kelompok penekan kebijakan yang proaktif dan aktif dalam interaksi di dalam analisis kebijakan publik. Menurut Howlett dan Ramesh dalam Madani (2011:37) 
aktor kebijakan meliputi aktor internal dan aktor eksternal yang mempunyai kosern tersendiri terhadap kebijakan. Dalam hal ini dilapangan dapat ditemukan kesesuaian prilaku aktor eksternal dan internal dimana aktor eksternal yakni Tim Wahana Pemekaran Himpunan Masyarakat Sebatik yang cukup proaktif dan aktif mengawal pemekaran daerah Kota Sebatik dari berbagai dinamikan dan perjalanan tim ini mampu mendorong aktor internal untuk mengeluarkan keputusan-keputusan daerah. Kemudian Menurut Pal dalam Widodo (2013), terdapat tiga tipe gaya analisis kebijakan diantaranya gaya analisis Proses Kebijakan hal ini lebih memperhatikan pada ketetapan dalam proses politik, keputusan, debat, konflik dan kompromi yang menghasilkan sebuah kebijakan publik. Pola lahirnya kebijakan dari pisau analisis proses tidak hanya melihat dari sisi isi atas keputusan kebijakan yang diambil karena muatan politik luar juga menjadi faktor variabel dalam hal ini aktor daerah yang berperan aktif telah mencoba menyelesaikan dan mengawal pemekaran daerah kota sebatik sampai pada tahapan pusat akan tetapi tarik ulur ditingkat pusat membuat proses pengawalan kebijakan pemekaran daerah Sebatik sedikit terhambat dapat terlihat berdasarkan hasil wawancara yang diuraikan salah satu tim wahana yang mengetahui secara pasti seluk beluk komunikasi kompromi di tataran aktor pusat.

Permasalahan proses perumusan kebijakan pemekaran Kota Sebatik intelektual ini sudah melakukan tugasnya dengan baik untuk mengawal dan mengkritik secara solutif tentang kebijakan pengawalan Pemekaran daerah Kota Sebatik dari aksi demonstrasi sampai kritik lewat media sosial juga turut serta dilakukan artinya pengaruh untuk melakukan sesuatu yang ideal terus menerus digencarkan dari beberapa tahun terakhir namun sayangnya pengaruh tersebut seolah tak didengarkan aktor-aktor yang ada di dalam pemerintahan baik pusat dan daerah, yang terjadi hanya umbar janji momentum politik tapi dalam komitmen bersama satu persatu tak mendengarkan. Kekuatan yang teman-teman bangun diluar sistem pemerintahan tidak begitu berpengaruh besar hanya sebatas isu-isu walaupun sebenarnya ditujukan kepada sikap aktor daerah yang tidak mempunyai tekad keseriusan dalam mengawal kebijakan pemekaran daerah kota Sebatik yang ada ditingkatan pusat.

\section{Kesimpulan}

Pemekaran daerah diartikan sebagai proses pelimpahan wewenang kekuasaan dari pemerintah pusat kepada pemerintah daerah. Jika dilihat fenomena yang ada selama ini demokrasi tersebut hanyalah sebagai euforia demokrasi lokal dimana semua yang terjadi kegembiraan sesaat yang menggambarkan bahwa proses politik hanya berlansung dalam situasi darurat jangka pendek, itu tidak bakal membuahkan demokrasi lokal yang kokoh dan berkelanjutan kecuali hanya menghasilkan instabilitas, kekecewaan yang mendalam masyarakat lokal yang tidak bisa merasakan kesejahteraan. Adapun kita harus ketahui bersama sebatik mampu membuktikan bahwa khususan adalah bagian utama untuk dimekarkan sebagai Kota Sendiri karena sebatik adalah tapal batas yang berbatasan langsung secara geografis dengan negara Malaysia baik daratan maupun lautannya. Sedangkan di dalam alur skema proses perumusan kebijakan perjalanan cukup panjang yang telah dilewati dan tidak terbilang mudah berawal dari isu sampai pada tahapan keputusankeputusan pemerintah daerah yang memutuskan pemekaran daerah Sebatik walau dasar tersebut didasarkan jika ditarik benang merahnya melalui analisis proses ada kemungkinan hal demikian muncul dari momentum pilkada sehingga aktor daerah (Bupati) berusaha mengawal sampai pada tingkatan pusat karena dorongan dari janji kesepakatan dengan Tim wahana Pemekaran (HMS) yang secara administratif prosedural mewadahi kepentingan pemekaran daerah Pulau Sebatik. Kemudian di dalam proses panjang perumusan kebijakan yang berlangsung Tim Wahana Pemekaran Sebatik selaku salah satu kunci yang mengawal dan memperjuangkan Pemekaran Sebatik kurang memprihatinkan desa-desa yang menjadi titik kunci keberlangsungan dan kesuksesan dalam Pemekaran Daerah Pulau Sebatik untuk persiapan Sebatik Kota hal ini dapat dilihat banyak terjadi miss komunikasi ditingkatan desa pasca desa mengeluarkan keputusan kebijakan desa tersebut tidak tahu sudah sejauh mana pengawalan yang dilakukan oleh Tim Wahana Pemekaran. Akhir kisah panjang proses perumusan kebijakan pemekaran daerah Pulau Sebatik ditahun 2013-2015 sampai pada tahapan pusat yakni di DPR RI dan kabar terakhir pada tahun 2016 akan disahkan menjadi kota sendiri sesuai dengan janji Presiden Joko Widodo dan kementrian terkait.

\section{Daftar Pustaka}

Azwar, S. (1996). Tes Prestasi Fungsi dan Pengembangan Pengukuran Prestasi Belajar. Yogyakarta: Pustaka Belajar.

Dunn, W.N. (2003). Pegantar Analisis Kebijakan Publik. Yogyakarta: UGM

Dye, T.R. (2005). Understanding Public Policy. New Jersey: Pearson Education Inc.

Islamy, I. (1989). Prinsip-prinsip Perumusan Kebijaksanaan Negara. Jakarta: Bina Aksara.

Islamy, I. (2003). Dasar-dasar Administrasi Publik dan Manajemen Publik. Malang: UB Press.

Madani, M. (2011). Kebijakan Publik, dimensi interaksi aktor dalam proses perumusan. Ed I. Graha Ilmu, Yogyakarta. 
Moleong, L.J. (2005). Metodologi Penelitian Kualitatif. Remaja Rosdakarya, Bandung.

Widodo, J. (2013). Analisis Kebijakan Publik (Konsep dan Aplikasi Analisis Proses Kebijakan Publik). Malang: Bayu Media. 